\title{
Chapter 3 \\ The Issue of Illicit Tobacco Trade in the UK
}

Illicit tobacco trade, as much as trade in other illicit products, is nothing new. ${ }^{1}$ Some have argued that it has probably existed since the introduction of tobacco as a valuable and sought-after product from the New World. A lot has been written about the topic and tobacco remains among the most traded products on the illicit market. ${ }^{2}$ Ultimately, illicit tobacco trade is the outcome of demand and supply. This is true for the UK as well. Consumers wish to save money, demanding cheaper or not available tobacco products, while illicit suppliers wish to make money and are thus interested in meeting demand to ensure larger sales, increased market shares, and greater profit. It is therefore generally accepted that only a combination of targeted policy and operational law enforcement measures addressing both supply and demand can stem illicit tobacco trade. This important premise underpins the holistic strategies implemented by the $\mathrm{EU}^{3}$ and the $\mathrm{UK}^{4}$ to counter illicit tobacco trade.

Assessing illicit tobacco trade is no easy task. As a clandestine activity by definition, illicit trade remains hidden until discovered. Experts have tried to estimate the impact of illicit tobacco at the global level. While acknowledging the difficulties related to the task, there appears to be a consensus which puts annual revenue loss in tobacco taxation worldwide at USD 40-50 billion, that is 600 billion sticks (individual cigarettes), equal to approximately $10 \%$ of global consumption. ${ }^{5}$ The ever evolving and adapting nature of illicit trade makes it hard to accurately account for it. Yet, collating data is essential for understanding the size and nature of the problem,

\footnotetext{
${ }^{1}$ Tobacco is not the only product that suffers from illicit trade. Solutions and recommendations against illicit tobacco trade can, to some extent, also apply to other industries. Conversely, solutions already applied to other industries (for instance pharma, fashion or defence) can inspire the development of solutions for illicit tobacco trade as well.

${ }^{2}$ See, for instance, Allen (2017).

${ }^{3}$ OLAF (2018) New Action Plan reaffirms Commission in leading role in fight against cigarette smuggling.

${ }^{4}$ HMRC and UK Border Force (2015) Tackling illicit tobacco: From leaf to light The HMRC and Border Force strategy to tackle tobacco smuggling.

${ }^{5}$ World Bank (2019). 
identifying and where possible anticipating emerging issues, devising countermeasures, and regularly assessing the effectiveness of the chosen strategy with a view to constantly refine and improve it.

\subsection{Definition and Forms of Illicit Trade}

Pursuant to Art. 1 (a) of the WHO FCTC, 'illicit trade' means "any practice or conduct prohibited by law and which relates to production, shipment, receipt, possession, distribution, sale or purchase including any practice or conduct intended to facilitate such activity". Illicit trade can be undertaken both by illicit players who are not registered with the relevant government agencies, as well as by legitimate entities whose business operations are contrary to applicable laws and regulations. Illicit tobacco can derive from illicit domestic production or from illicit imports.

- Illicit domestic production is where tobacco products which are manufactured for consumption in the same jurisdiction are not declared to tax authorities. Products (which may be genuine or counterfeit) are sold without applicable taxes and may be manufactured in approved factories or as part of illegal covert operations.

- Illicit imports refer the unlawful movement of tobacco products from one tax jurisdiction to another without the payment of applicable taxes, or in breach of laws prohibiting their import or export.

Illegal imports involve products that can be genuine, counterfeit, or so-called 'cheap whites' or 'illicit whites' ${ }^{6}$ The illicit import of genuine products is often considered 'old school' large-scale cigarette smuggling, whereas counterfeit products are manufactured illegally-i.e. they bear a trademark without the owner (or authorized manufacturer's) consent. 'Cheap whites' or 'illicit whites' are terms used to describe cigarettes produced legally in one country, usually by smaller, low-profile businesses without trademark infringement, but have no legitimate market and are manufactured with the intent of being smuggled and sold outside of their country of production. Finally, illicit imports also include the abuse of legal privileges, i.e. situations where buyers/consumers exceed their allowances for imports of otherwise licit tobacco products.

These patterns, with some variations, apply to trade in all tobacco products, including cigarettes, hand rolling tobacco (HRT), and cigars. Illicit trade adjusts to the introduction of new legislation. Constantly seeking ways to circumvent control measures, it is receptive to new consumer trends and to new instruments and channels that can be used to reach customers. Like other activities, both licit and illicit, illicit tobacco traders are well aware of the business opportunities that the digital revolution offers. Social media, the growth of e-commerce, and the proliferation of postal and small parcel delivery services are revolutionizing the way consumers choose and purchase their favourite products. Unsurprisingly, these new trends are also having an impact

${ }^{6}$ See, for instance, Allen (2017). 
on illicit trade in tobacco products. Small parcel delivery service in particular, has emerged as an issue of great concern. Already in 2016, a survey by the Organization for Economic Co-operation and Development (OECD) identified the growing volume of small parcels in the postal system as a "major threat to the [authorities'] ability to combat illicit trade". ${ }^{7}$ OECD and the European Union Intellectual Property Office (EUIPO) have also signalled how tobacco products are among the main fake product categories shipped via small parcels to the EU. ${ }^{8}$

Most trade in tobacco products is a perfectly licit (albeit tightly regulated and taxed) activity. Today, the UK has no commercial tobacco leaf production and its domestic manufacturing of cigarettes is marginal. The tobacco industry has been steadily reducing its workforce over several decades, largely as a result of mechanisation and rationalisation. The last two producers, Imperial Tobacco and Japan Tobacco International, closed their factories in Nottingham and in Northern Ireland in 2016 and 2017 respectively. ${ }^{9}$ Absent domestic production, the licit tobacco market in the UK, for cigarettes and for other products, is comprised of imports. In 2018, the UK's top six import sources of tobacco products were all EU Member States, namely Poland, Germany, the Netherlands, Romania, and Belgium. ${ }^{10}$

Government data reports that in 2017, 28.6 billion sticks were released in the UK, a decrease from 2016 (30.9 billion) and 2015 (32.6 billion). Sales of cigarettes for home consumption have continued to fall since the mid-1990s and the quantity released in 2017 is 66\% less than in 1996. Hand-rolled tobacco (HRT) shows an opposite trend. Since 1990, there has been an increase in the proportion of UK smokers using these products. Sales of HRT more than doubled between 2004 and 2012, reflecting the increase in the proportion of adults who smoked hand-rolled cigarettes. This trends remained fairly steady since $2012 .^{11}$

\subsection{The Duty-Free Regime (Personal Allowances)}

Beside domestic sales, tobacco can be brought into the UK legally by consumers themselves (personal allowances). Currently, consumers do not pay duty or tax on tobacco products that they bring in from the EU if the following three conditions are cumulatively fulfilled: (1) the products are transported by the consumers; (2) the products are used by the consumers or given away as a gift; and (3) duty and tax have been paid in the EU country where consumers bought them. Although there

\footnotetext{
${ }^{7}$ OECD (2018) Governance Frameworks to Counter Illicit Trade, p. 79.

${ }^{8}$ OECD and EUIPO (2018) Misuse of Small Parcels for Trade in Counterfeit Goods: Facts and Trends.

${ }^{9}$ The two companies still dominate the licit cigarette market in the UK with a combined market share of around $80 \%$.

${ }^{10}$ Statista.com (2019) Leading 5 importing countries of tobacco into the United Kingdom in 2018, ranked by value (in $1000 \mathrm{GBP}$ ).

${ }^{11}$ NHS (2018) Statistics on Smoking—England, 2018.
} 
are no limits on the amount of tobacco that can be brought in from EU countries, since the goods are meant for self-consumption and not for resale, guide levels are provided to help customs officers distinguish between genuinely private imports and commercial importation. Border control is likely to enquire if the amounts carried exceed 800 cigarettes, 200 cigars, 400 cigarillos or $1 \mathrm{~kg}$ of tobacco per person. ${ }^{12}$ For imports from non-EU Member States, the duty-free regime applies. ${ }^{13}$ Accordingly, passengers traveling from non-EU Member States to the UK can bring in, without paying duty or tax, one of the following: 200 cigarettes, 100 cigarillos, 50 cigars, or $250 \mathrm{~g}$ tobacco. ${ }^{14}$ Quantities that exceed the personal allowance have to be declared and are subject to applicable duties and taxes. The possible impact of Brexit on the personal allowances for tobacco products is presented in Sect. 4.1.1 below.

\subsection{UK Illicit Tobacco Trade Data}

Data on the illicit tobacco trade in the UK comes from two source-the UK government, and the tobacco industry itself. Trends from these two sources are reported in this section, along with a comparison with EU-wide trends.

\subsubsection{UK Government Information}

Illicit tobacco trade exists, as proven on the supply side by the regular seizure of tobacco products, and on the demand side by public perception surveys. According to the World Customs Organization (WCO), in 2017 customs officers from 91 countries provided data on 12,228 cases involving goods being smuggled to avoid excise taxes. Primarily, these goods were alcohol products and tobacco products, including cigarettes. ${ }^{15}$ According to the 2016 survey commissioned by the European Anti-Fraud Office (OLAF) to Eurobarometer titled 'Public perception of illicit tobacco trade', $21 \%$ of the respondents in the UK revealed to have been offered black market cigarettes to smoke. ${ }^{16}$ Estimating or even quantifying illicit markets, however, is methodologically challenging. Data provided by Government and private industry-commissioned initiatives do not always correspond. ${ }^{17}$ Some commentators

\footnotetext{
${ }^{12} \mathrm{HM}$ Government (2020) Bringing goods into the UK.

${ }^{13}$ Ibid.

${ }^{14}$ It is possible to split the allowance, e.g. 100 cigarettes and 25 cigars.

${ }^{15}$ In total, 14,786 seizures of alcohol, cigarettes, and other tobacco products were reported, with the recovery of $379,956,831$ cigarette pieces, 468,778 cigars and 1,399,381.5 $\mathrm{kg}$ of other tobacco products. World Customs Organization (2017), p 147.

${ }^{16}$ EC Eurobarometer (2016a) Illicit Tobacco Trade-United Kingdom.

${ }^{17}$ The study Trajectory (2016), funded by SICPA, highlights how figures from different studies are at often odds.
} 
have criticized industry-commissioned studies, claiming that they overestimate illicit trade, feature substantial methodological problems, and fail to meet the standards of accuracy and transparency that are set by high-quality publications. ${ }^{18}$

For 2018, the UK Government estimates the illicit market share for cigarettes and HRT at $9 \%$ and $32 \%$, respectively. There has been a clear downward trend from the all-time high reached in the 1990s, with the biggest drop occurring in the first decade of 2000. During that period, the illicit market share for cigarettes was nearly halved, decreasing from 22 to $12 \%$. The illicit market share for HRT saw a decrease from 61 to $44 \%$ during the same period. For cigarettes, the decrease has been consistent, with only a few exceptions in 2012-2014 and again between 2016 and 2017. The reduction is confirmed in the 2017-2018 period, the most recent timeframe for which estimates are currently available, with a drop from $15 \%$ to $9 \%$ between the 2016 2017 and the 2017-2018 periods. Overall, the illicit market share for HRT, is also decreasing, although it still captures a significantly more important portion of the market than cigarettes, and in the most recent period it has registered a slight increase (from 27 to $32 \%)^{19}$

One of the most immediate and tangible consequences of illicit tobacco trade is the tobacco tax gap. ${ }^{20}$ Data, covering the 2017-2018 period, estimates the tobacco tax gap at $£ 1.8$ billion. Cigarettes and HRT contribute to the tax gap with $£ 1.0$ billion and $£ 0.8$ billion, respectively. The cigarette tax gap has experienced a sharp decrease from the previous period (2016-2017), when it stood at $£ 1.6$ billion. The HRT tax gap on the contrary increased, although very modestly, from $£ 0.7$ to $£ 0.8$ billion in the 2017-2018 period. The tax gap tends to reflect the downward trend in the illicit cigarettes market share. For HRT the overall trend is also downward with a slight increase in the most recent years. ${ }^{21}$

\subsubsection{Tobacco Industry Information}

Non-governmental initiatives also collect and publish data on tobacco consumption and illicit tobacco trade estimates. For instance, according to the 2019 KPMG Stella Project, total cigarette consumption in the UK for 2018 stood at 36.7 billion sticks ( $-2 \%$ compared to 2017). Illicit cigarettes, defined in the study as 'contraband and counterfeit (C\&C)', amounted to 7.1 billion sticks ( $+0.2 \%$ compared to 2017 ), which is equal to $19.3 \%(+1.4 \%$ compared to 2017$)$ of total consumption. The total tax revenue loss from illicit cigarettes in 2018 amounted to $£ 2.772$ million (+65 million from 2017). Both figures, are higher than the HMRC estimates presented above for the same year.

\footnotetext{
${ }^{18}$ See, for instance, Gallagher et al. (2019).

${ }^{19}$ NHS (2019) Statistics on Smoking—England, 2019.

${ }^{20}$ On the methods used by the UK Government to estimate illicit market shares and associated revenue losses. See World Bank (2019) pp. 188-189.

${ }^{21}$ NHS (2019) Statistics on Smoking-England, 2019.
} 
The Tobacco Manufacturers Association (TMA) Smokers' Anti-Illicit Trade Survey, lastly conducted in 2018, highlights the attitudes, awareness, and understanding of smokers toward illicit tobacco in the UK. ${ }^{22}$ The survey of over 12,000 adult smokers suggests that the number of smokers avoiding UK duty now stands at an all-time high, and that "over three-quarters are regularly avoiding taxes by buying tobacco from the black market [illicit], abroad or duty free [licit as long as the personal allowances are not exceeded]". The findings also suggest that adult smokers are being pushed towards non-UK duty tobacco by high tobacco taxation, the introduction of plain packaging, and the recent ban on minimum tobacco pack sizes. $^{23}$

With regard to the patterns of illicit trade, the data available is unanimous in concluding that, with the notable exception of Gibraltar, the UK is target market (ending point). ${ }^{24}$ It is neither a transit or origin point. The 2018 KPMG's Stella Project found that, with the exception of Ukraine, inflows to the UK are principally from holiday destinations (Spain) and countries with large UK emigrant communities (Poland and Romania). ${ }^{25}$

Illegal cigarettes arrive in the UK mainly by water, motor vehicle, or air flight. Ports are crucial junctions for illicit trade in tobacco products and in particular those well connected with other transport infrastructures. According to the $2018 \mathrm{KPMG}$ Stella Project, the fact that volumes of illicit cigarettes seem to be higher in the North East of England may be explained by the fact that inflows may have originated through sea-ports. ${ }^{26}$

Information relating to seizures can help in understanding the patterns of illicit tobacco trade. ${ }^{27}$ The Project SIA 'Seizure Insight Analysis, Tobacco Product seizures in the EU, Norway and Switzerland', launched in 2019 by KMPG and commissioned by Philip Morris International (PMI), collates valuable information on seizures of illicit tobacco products. ${ }^{28}$ The study reported 1301 seizures in the UK in the $2015-$ 2018 period. Ports were the most common seizure location whereas retail shops were

\footnotetext{
${ }^{22}$ TMA (2018) TMA Smokers' Anti-Illicit Trade Survey 2018: Attitudes, Awareness and Understanding. The Tobacco Manufacturers' Association (TMA) is the trade association for the UK tobacco industry. The TMA's members are British American Tobacco UK Ltd., Imperial Tobacco Ltd. and Gallaher Ltd. (a member of the Japan Tobacco Group of companies).

${ }^{23}$ TMA (2018) TMA Smokers' Anti-Illicit Trade Survey 2018: Attitudes, Awareness and Understanding.

${ }^{24}$ Calderoni et al. (2013).

${ }^{25}$ KPMG (2019b) Project Stella, Report for the United Kingdom.

${ }^{26}$ Ibid.

${ }^{27}$ While the data based on seizures is solid, using it to estimate the total size of the illicit tobacco market is risky as the exercise implies setting a rate of interception of smuggled products. Some observers have assumed that maybe $10 \%$ of the illicit trade is intercepted, although the effective interception rate is likely to be lower. See European Commission (2016).

${ }^{28}$ KPMG (2019a) Project SIA-Seizure Insight Analysis, Tobacco Product seizures in the EU, Norway and Switzerland.
} 
the most common seizure premise. During the same period, 473.9 million sticks were seized, with a median size of 10.5 thousand sticks per seizure. The total value of the products seized (cigarettes and raw tobacco) amounted to $€ 642.5$ million. ${ }^{29}$

The digital era is impacting illicit trade in tobacco products and the UK is no exception. Studies show how illicit tobacco products are distributed online through three main channels: social media platforms, purpose-built hosted websites, and online marketplaces. ${ }^{30}$ In some instances, Facebook, Instagram and Snapchat have been used to market illicit products directly to consumers and organise face-toface transactions. ${ }^{31}$ The modus operandi is being studied. The information available suggests that online sellers are not necessarily the same individuals that bring illicit products into the UK. Illicit products are often brought into the country by organised criminal groups and subsequently supplied to smaller-scale vendors who then resell online. ${ }^{32}$

The magnitude of this phenomenon clearly emerges from Operation Jasper, a multi-agency effort launched in 2015 and led by the National Markets Group for Intellectual Property Protection with the participation of over 100 Trading Standards. Operation Jasper targets sellers of illicit goods on social media and markets including counterfeit and pirated goods offered on Facebook and Instagram. Since inception, it has led to 20,000 infringing listings being removed from Facebook, full profiles being closed, 120+ raid actions and investigations being commenced, and several thousand counterfeit and pirated products being seized. ${ }^{33}$ The collected intelligence shows links between the online and offline sale of counterfeit and pirated goods, and permits the identification of solid connections between intellectual property crime and other forms of criminality. Such an approach also allows for the engagement of platform owners, such as Facebook, regarding the issue of criminal use of internet platforms. Beside social media, purpose-built hosted websites, created to sell illicit

\footnotetext{
${ }^{29}$ The study reports the top seizures. In 2017 more than 100 tonnes of imported raw tobacco uncovered during a nationwide investigation that centred on Lancashire, whereas in February of the same year, more than 50 tonnes of illicit rolling tobacco were seized from a factory in east Lancashire and in December 2017, 22 tonnes of illegal tobacco were seized while being smuggled into Hull dock, the tobacco was discovered in a HGV lorry that had arrived from Rotterdam. KPMG (2019a) Project SIA-Seizure Insight Analysis.

${ }^{30}$ Illicit trade in tobacco products on "darknet" in Europe seems marginal. Darknet markets consist of websites, which are in many ways similar to other online platforms that facilitate trade, such as eBay or Amazon. The key difference is the anonymity afforded by accessing darknet markets. The darknet is part of the deep web, the part of the internet that is not accessible by standard web browsers, but is used for storing encrypted data such as government files and personal banking records.

${ }^{31}$ Most sales organized over social media do not seem to involve the use of postal or parcel services and rather result in face-to-face transactions with payment made in cash. One could refer to this trend as "digitalization of street selling". Babuta et al. (2018), p. 17.

${ }^{32}$ Babuta et al. (2018), p. 18.

${ }^{33}$ UK-IPO (2018) IP Crime and Enforcement Report 2017-2018. See also The National Trading Standards (2016). The National Trading Standards eCrime Team (NTSeCT) has been set up by the National Trading Standards Board and by the Department of Business, Innovation and Skills to investigate online scams and rip-offs of national significance.
} 
tobacco products online, offer customers the possibility to pay by credit card and organise delivery by post. A third channel is made of online marketplaces, such as eBay and Amazon. ${ }^{34}$

Recent studies also show how the use of postal and parcel services to import illicit tobacco products is perceived as a prevalent and growing issue in the UK. According to a 2018 study by the Royal United Services Institute for Defence and Security Studies (RUSI), online channels are not only used by opportunist individual sellers, but also by organised criminals with international contacts, access to a steady supply of illicit products, and sophisticated distribution networks. Social behaviour and falling prices offered by many delivery providers suggest that more and more illicit consignments (including tobacco products) are being sent through postal channels, hidden in plain sight among a sea of other packages. ${ }^{35}$

\subsubsection{Comparison with EU-Wide Data}

OLAF, the European Anti-Fraud Office, estimates that illicit trade in tobacco products at the EU level drains $€ 10$ billion from EU and Member State budgets every year. ${ }^{36}$ Industry studies, such as the KPMG Project Stella commissioned by PMI, estimates illicit cigarette in the EU for the year 2018 at $8.6 \%$ of total consumption, representing 43.6 billion cigarettes. ${ }^{37}$ This figure is comparable to the size of the total legal cigarette sales in the UK, Austria, and Denmark combined.

According to KPMG, overall illicit cigarette consumption levels remained stable compared to $2017 .{ }^{38}$ However, the KPMG report found a more than $30 \%$ increase in counterfeit consumption - the largest amount recorded to date. ${ }^{39}$ Among EU countries, the UK has the largest counterfeit cigarette volumes ( 0.9 billion cigarettes) after Greece (1.5 billion cigarettes). Two additional findings of the study are that non-EU countries remain the largest source of illicit cigarettes consumed in the EU-with a reduced incidence of illicit cigarette consumption in EU Eastern border countries-suggesting that law enforcement activities in those areas are bearing fruit.

\footnotetext{
${ }^{34}$ Babuta et al. (2018).

${ }^{35}$ Ibid.

${ }^{36}$ OLAF (2018) New Action Plan reaffirms Commission in leading role in fight against cigarette smuggling. However, a comprehensive and accurate picture of the illicit tobacco market is missing at EU level. To assist in improving strategic activities, in 2018 OLAF put out a tender for a study aimed at "identifying an approach to measure the illicit market in tobacco products". The study commissioned shall present a "reliable, robust, replicable and independent methodology which over time will provide a solid basis to analyse ongoing trends in the illegal tobacco market and respond effectively to anti-fraud requirements". https://etendering.ted.europa.eu/cft/cft-display.html?cftId= 3253.

${ }^{37}$ Stop Illegal (2019) New KPMG report in the EU reveals largest increase of counterfeit cigarette consumption to date.

${ }^{38}$ Ibid.

${ }^{39}$ Ibid.
} 
Consumption of legal non-domestic cigarettes grew by $10 \%$ in 2018 , indicating that consumers purchased lower-priced products when travelling, rather than using the illicit market. ${ }^{40}$

At the EU level, smuggling of genuine product in large scale seizures has decreased in the past years. At the same time, cheap whites dominate large-scale seizures reported by Member States to OLAF. ${ }^{41}$ While cigarettes accounted for $24 \%$ of all detained articles (not just tobacco) at the EU external border in $2016,{ }^{42}$ detected illicit tobacco production in the EU also seems to be on the rise. Illegal production has also been registered near the UK border. For instance, an illegal factory dismantled in March 2018 in neighbouring Ireland had the capacity to produce a quarter of a million cigarettes per hour, according to a press release by the Revenue Commissioners in Ireland. ${ }^{43}$ A 2016 survey commissioned by OLAF to Eurobarometer titled Public perception of illicit tobacco trade, reveals that $19 \%$ of the respondents on a EU-wide basis have been offered black market cigarettes to smoke. ${ }^{44}$ The figure is slightly below that the average reported in the UK $(21 \%)$.

The data presented shows that today, the UK is a target country for the purpose of illicit trade in tobacco products. The country has only marginal domestic manufacturing capacity — both licit and illicit—and thus does not represent an important point of origin for illicit tobacco. Likewise, current data does not highlight situations where the UK territory is used as transit for illicit tobacco products from third countries en route to the markets of other EU countries. The analysis of the impact of Brexit on illicit trade thus focuses chiefly on the UK market, rather than that of the EU.

\section{References}

Allen E (2017) The illicit trade in tobacco products and how to tackle it, 2nd edn. International Tax and Development Center (ITIC), World Customs Journal Report

Babuta A, Haenlein C, Reid A (2018) E-commerce, delivery services and the illicit tobacco trade. Royal united services institute for defence and security studies (RUSI). https://www.rusi.org/sites/ default/files/20181016_ecommerce_delivery_services_illicit_tobacco_trade_web.pdf. Accessed $24 \mathrm{Feb} 2020$

Calderoni F, Favarin S, Ingrascì O, and Smit A (2013) The Factbook on the illicit trade in tobacco products 1 -United Kingdom. Transcrime. http://www.transcrime.it/pubblicazioni/the-factbookon-the-illicit-trade-in-tobacco-products-1/. Accessed 24 Feb 2020

Euractiv (2018) OLAF: illicit cut tobacco is a significant and growing market. https://www.euractiv. com/section/economy-jobs/news/olaf-illicit-cut-tobacco-is-a-significant-and-growing-market/. Accessed 27 Feb 2020

\footnotetext{
${ }^{40}$ Ibid.

${ }^{41}$ Euractiv (2018) OLAF: Illicit cut tobacco is a significant and growing market.

${ }^{42}$ European Commission (2018) OLAF-Policy_Joint Customs Operations.

${ }^{43}$ Republic of Ireland Revenue Dept (2018) Revenue and An Garda Siochana dismantle illicit cigarette factory in Jenkinstown.

${ }^{44}$ EC Eurobarometer (2016b) Penetration of Cigarettes in the Black Market, United Kingdom.
} 
EC Eurobarometer (2016a) Illicit tobacco trade-United Kingdom. European Commission Special Eurobarometer 443, July 2016. https://ec.europa.eu/anti-fraud/sites/antifraud/files/eb_illicit_ tobacco_trade_united_kingdom_en.pdf. Accessed $24 \mathrm{Feb} 2020$

EC Eurobarometer (2016b) Penetration of cigarettes in the black market, United Kingdom. European Commission Special Eurobarometer 443, July 2016. https://ec.europa.eu/anti-fraud/sites/ antifraud/files/eb_illicit_tobacco_trade_united_kingdom_en.pdf. Accessed 24 Feb 2020

European Commission (2016) Technical assessment of the experience made with the AntiContraband and Anti-Counterfeit agreement and general release of 9 July 2004 among Philip Morris International and affiliates, the Union and its Member States. Commission Staff Working document, Brussels, 24.2.2016. https://ec.europa.eu/anti-fraud/sites/antifraud/ files/technical_assessment_pmi_24022016_en.pdf. Accessed 24 Feb 2020

European Commission (2018) OLAF—policy—joint customs operations. https://ec.europa.eu/antifraud/policy/joint-customs-operations-jco_en. Accessed 27 Feb 2020

Gallagher AWA, Evans-Reeves KA, Hatchard JL, Gilmore AB (2019) Tobacco industry data on illicit tobacco trade: a systematic review of exiting assessments. BMJ J Tobacco Control 28(3):334-345

HM Government (2020) Bringing goods into the UK. Her Majesty's Government. https://www. gov.uk/duty-free-goods/arrivals-from-eu-countries, and https://www.gov.uk/duty-free-goods/ arrivals-from-outside-the-eu. Accessed $24 \mathrm{Feb} 2020$

HMRC and UK Border Force (2015) Tackling illicit tobacco: from leaf to light the HMRC and border force strategy to tackle tobacco smuggling. Government of the United Kingdom. https://assets.publishing.service.gov.uk/government/uploads/system/uploads/attachment data/file/418732/Tackling_illicit_tobacco_-_From_leaf_to_light_2015_.pdf. Accessed 24 Feb 2020

KPMG (2019a) Project SIA-seizure insight analysis, tobacco product seizures in the EU, Norway and Switzerland. KPMG. https://home.kpmg/uk/en/home/insights/2019/01/project-sia-tobaccoproduct-seizures-in-europe.html. Accessed $24 \mathrm{Feb} 2020$

KPMG (2019b) Project Stella report for the United Kingdom, 2019. KPMG. https://www.stopillegal. com/docs/default-source/external-docs/kpmg-project-stella/uk.pdf. Accessed 24 Feb 2020

NHS (2018) Statistics on smoking-England, 2018. National health service digital. https:// digital.nhs.uk/data-and-information/publications/statistical/statistics-on-smoking/statistics-onsmoking-england-2018. Accessed $24 \mathrm{Feb} 2020$

NHS (2019) Statistics on smoking-England, 2019. National health service digital. https:// digital.nhs.uk/data-and-information/publications/statistical/statistics-on-smoking/statistics-onsmoking-england-2019. Accessed 24 Feb 2020

OECD (2018) Governance frameworks to counter illicit trade. Organisation of Economic Cooperation and Development Publishing

OECD and EUIPO (2018) Misuse of small parcels for trade in counterfeit goods: facts and trends. OECD Publishing. https://doi.org/10.1787/9789264307858-en

OLAF (2018) New action plan reaffirms commission in leading role in fight against cigarette smuggling. European Anti-Fraud Office, Press Release No. 13/2018. https://ec.europa.eu/ anti-fraud/media-corner/news/07-12-2018/new-action-plan-reaffirms-commission-leading-rolefight-against_en. Accessed 24 Feb 2020

Republic of Ireland Revenue Dept (2018) Revenue and An Garda Siochana dismantle illicit cigarette factory in Jenkinstown, Co. Louth. Revenue Department of the Republic of Ireland, 15 Mar 2018. https://www.revenue.ie/en/corporate/press-office/press-releases/2018/pr-150318illegal-cigarette-factory-jenkinstown-louth.aspx. Accessed 24 Feb 2020

Statista.com (2019) Leading 5 importing countries of tobacco into the United Kingdom in 2018, ranked by value (in 1000 GBP). https://www.statista.com/statistics/305181/uk-tobacco-importsleading-5-countries-by-value/. Accessed $24 \mathrm{Feb} 2020$

Stop Illegal (2019) New KPMG report in the EU reveals largest increase of counterfeit cigarette consumption to date. Stop Illegal, 11 June 2019. https://www.stopillegal.com/blog/detail/new- 
kpmg-report-in-the-eu-reveals-largest-increase-of-counterfeit-cigarette-consumption-to-date. Accessed 24 Feb 2020

The National Trading Standards (2016) Products worth millions seized in counterfeiting crackdown. National trading standard, 23 Dec 2016. https://www.nationaltradingstandards.uk/news/productsworth-millions-seized-in-counterfeiting-crackdown/. Accessed 24 Feb 2020

TMA (2018) TMA smokers' anti-illicit trade survey 2018: attitudes, awareness and understanding. Tobacco Manufacturers' Association. http://the-tma.org.uk/2018/08/20/survey-reveals-thebuying-of-untaxed-tobacco-hits-an-all-time-high-2/. Accessed 24 Feb 2020

Trajectory (2016) Turning point: insights into illicit tobacco in the UK. Trajectory, July 2016. https://trajectorypartnership.com/wp-content/uploads/2016/07/Trajectory-paper-Illicit-tobaccotrade-UK-060716.pdf. Accessed 24 Feb 2020

UK-IPO (2018) IP crime and enforcement report 2017-2018. United Kingdom intellectual property office. https://assets.publishing.service.gov.uk/government/uploads/system/uploads/ attachment_data/file/740124/DPS-007593_IP_Crime_Report_2018_-_Web_v2.pdf. Accessed $24 \mathrm{Feb} 2020$

World Bank (2019) Confronting illicit tobacco trade-a global review of country experiences, United Kingdom. World Bank. http://pubdocs.worldbank.org/en/248361548435105081/WBGTobacco-IllicitTrade-UnitedKingdom.pdf. Accessed 24 Feb 2020

World Customs Organization (2017). 2017 illicit trade report. World customs organization. http://www.wcoomd.org/-/media/wco/public/global/pdf/topics/enforcement-and-compliance/ activities-and-programmes/illicit-trade-report/itr_2017_en.pdf?db=web. Accessed 24 Feb 2020

Open Access This chapter is licensed under the terms of the Creative Commons Attribution 4.0 International License (http://creativecommons.org/licenses/by/4.0/), which permits use, sharing, adaptation, distribution and reproduction in any medium or format, as long as you give appropriate credit to the original author(s) and the source, provide a link to the Creative Commons license and indicate if changes were made.

The images or other third party material in this chapter are included in the chapter's Creative Commons license, unless indicated otherwise in a credit line to the material. If material is not included in the chapter's Creative Commons license and your intended use is not permitted by statutory regulation or exceeds the permitted use, you will need to obtain permission directly from the copyright holder.

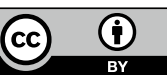

